\title{
Floral Diversity for Foraging of the Asiatic Honey Bee, Apis cerana indica (Hymenoptera: Apidae) in Madurai District of Tamil Nadu, India
}

\author{
D. Hemalatha ${ }^{*}$, J. Jayaraj ${ }^{2}$, M. Murugan ${ }^{3}$, T.N. Balamohan ${ }^{4}$, N. Senthil ${ }^{5}$, \\ C. Chinniah ${ }^{1}$ and K. Suresh ${ }^{1}$
}

${ }^{1}$ Department of Agric. Entomology, Agricultural College and Research Institute, Madurai, Tamil Nadu, India

${ }^{2}$ Department of Agric. Entomology, Grapes Research Station, Rayappanpatti, Theni, Tamil Nadu, India

${ }^{3}$ Department of Differently Abled Studies, Community Science College and Research Institute, Madurai, Tamil Nadu, India

${ }^{4}$ Department of Horticulture, Agricultural College and Research Institute, Madurai, Tamil Nadu, India

${ }^{5}$ Department of Biotechnology, Tamil Nadu Agricultural University, Coimbatore,

Tamil Nadu, India

*Corresponding author

\section{A B S T R A C T}

\section{Keywords}

A. cerana indica,

Foraging flora, Pollen

yielder, Nectar yielder

Article Info

Accepted:

24 September 2018

Available Online:

10 October 2018
The Asiatic honey bee, Apis cerana indica harvests pollen and nectar from the flowers and helps in pollination process. Bee pasturage in the location is essential for better management of the hives and improving the yield. Floral diversity in the Madurai region was studied which revealed that the flora was belonging to 76 families. Among them family Fabaceae contributed a maximum of 31 species $(12.25 \%)$ followed by Asteraceae $6.72 \%$ with 17 flora, Caesalpiniaceae (5.53\%) and Cucurbitaceae (4.74\%). The grouping of bee pasturage revealed that 41 were nectar yielders, 30 were pollen yielders and 182 of both nectar and pollen yielders.

\section{Introduction}

Honey bees harvest pollen and nectar from the flowers and help in pollination process (Dalio, 2015 and Kumar and Sharma 2016). One third of the crops rely exclusively on insect pollination only. It is estimated that one third of human food supply depends on insect pollination (Jivan, 2013; Said et al., 2015). Indian bee, Apis cerana indica Fabricius is an economically important, domesticated honey bee species in southern part of India (I'anson Price and Gruter, 2015). It has been distributed in China, Japan, India, Bangladesh, Nepal, Papua New Guinea and Malaysia (Egelie et al., 2015; Theisen-Jones and Bienefeld, 2016). Pollen and nectar from 
plants are the prime food for bees. Bee bread, which is the mixture of pollen and honey is given to young ones with royal jelly. Bee pasturage in the location is essential for better management of the hive and improving the yield (Sodre et al., 2007). With this concept investigations were carried out to identify the floral diversity in the southern part of Tamil Nadu.

\section{Materials and Methods}

The study area was the Agricultural College and Research Institute, Madurai of Tamil Nadu, India, which was located at the latitude of $9^{\circ} 55^{\prime} 25.79^{\prime \prime} \mathrm{N}$, longitude of $78^{\circ} 05^{\prime} 27.00^{\prime \prime} \mathrm{E}$ and altitude of 331 feet mean sea level. The study area was surrounded by agricultural, horticultural crops and natural vegetation of foot hills of Yanaimalai rock. Indian honey bee, A. cerana indica colonies in 25 Newton hives were maintained in the above said location. All the colonies were with eight frames $(13 \times 21 \mathrm{~cm})$ in brood chamber and eight frames in $(6.5 \times 21 \mathrm{~cm})$ super chamber having approximate of $10000-12000$ bees. The study was conducted during 2016 to 2017.

Foraging flora was studied regularly once in a week during the entire study period. Observations were taken from 6.00 to $18.00 \mathrm{hr}$ by recording different flowering plant species on which the bee performs foraging. Bee foraging plants were confirmed by the visit of bees and successful foraging of at least three bees within 10 minutes period of observation as described by Bhalchandra et al., 2014.

The identified flora was further grouped into nectar, pollen and both nectar and pollen supplying plants. Nectar source was determined by extension of proboscis by the bee into the flower for nectar collection and pollen source was determined by the presence of pollen in the hind legs of bees. The plants were identified by the help of published reports, experts and online services.

\section{Results and Discussion}

The identified plants of bee forage of 76 families were, Acanthaceae, Agavacea, Aizoaceae, Alliaceae, Amaranthaceae, Anacardiaceae, Annonaceae, Apiaceae, Apocynaceae, Aracaceae, Asclepidaceae, Asteraceae, Balsaminaceae, Bignoniaceae, Bombacaceae, Boraginaceae, Brassicaceae, Caesalpiniaceae, Cannaceae, Caricaceae, Chenopodiaceae, Cleomaceae, Clusiaceae, Combretaceae, Commelinaceae, Compositae, Convolvulaceae, Cucurbitaceae, Cyperaceae, Dioscoreaceae, Elaeocarpaceae, Euphorbiaceae, Fabaceae, Lamiaceae, Lecythidaceae, Leguminosae, Liliaceae, Lythraceae, Malvaceae, Martyniaceae, Meliaceae, Mimosaceae, Moraceae, Moringaceae, Musaceae, Myrtaceae, Nelumbonaceae, Nyctaginaceae, Oleaceae, Nymphaeaceae, Oxalidaceae, Papavarace, Pedaliaceae, Piperaceae, Poaceae, Polygonaceae, Portulacaceae, Punicaceae, Rhamnaceae, Rosaceae, Rubiaceae, Rutaceae, Sampigae, Santalaceae, Sapindaceae, Sapotaceae, Scorphulariaceae, Simaroubaceae, Solanaceae, Tiliaceae, Typhaceae, Ulmaceae, Urticaceae, Verbenaceae, Zingiberaceae and Zygophyllaceae (Table 1).

Among these 76 families Fabaceae contributes a maximum of 31 species (12.25\%). Asteraceae $(6.72 \%)$ contributing 17 species of bee foraging flora followed by Caesalpiniaceae $(5.53 \%)$, Cucurbitaceae $(4.74 \%)$ and $4.35 \%$ compositely contributed by Amaranthaceae, Euphorbiaceae and Lamiaceae (Table 1). The bee flora accounted in our study location was 253. Majority of them were Fabaceae, Asteraceae, Caesalpiniaceae, Cucurbitaceae, Euphorbiaceae, Amaranthaceae, Lamiaceae, Mimosaceae and Acanthaceae. 
Table.1 Family wise distribution of bee flora in Madurai district during 2016 - 2017

\begin{tabular}{|c|c|c|c|c|c|c|c|}
\hline $\begin{array}{l}\text { S. } \\
\text { No. }\end{array}$ & Family & $\begin{array}{l}\text { No. of } \\
\text { species }\end{array}$ & $\begin{array}{c}\text { Percent } \\
\text { contribution } \\
(\%)\end{array}$ & $\begin{array}{l}\text { S. } \\
\text { No. }\end{array}$ & Family & $\begin{array}{l}\text { No. of } \\
\text { species }\end{array}$ & $\begin{array}{c}\text { Percent } \\
\text { contribution } \\
(\%)\end{array}$ \\
\hline 1 & Fabaceae & 31 & 12.25 & 39 & Boraginaceae & 1 & 0.40 \\
\hline 2 & Asteraceae & 17 & 6.72 & 40 & Cannaceae & 1 & 0.40 \\
\hline 3 & Caesalpiniaceae & 14 & 5.53 & 41 & Caricaceae & 1 & 0.40 \\
\hline 4 & Cucurbitaceae & 12 & 4.74 & 42 & Chenopodiaceae & 1 & 0.40 \\
\hline 5 & Amaranthaceae & 11 & 4.35 & 43 & Cleomaceae & 1 & 0.40 \\
\hline 6 & Euphorbiaceae & 11 & 4.35 & 44 & Clusiaceae & 1 & 0.40 \\
\hline 7 & Lamiaceae & 11 & 4.35 & 45 & Combretaceae & 1 & 0.40 \\
\hline 8 & Mimosaceae & 10 & 3.95 & 46 & Cyperaceae & 1 & 0.40 \\
\hline 9 & Acanthaceae & 9 & 3.56 & 47 & Dioscoreaceae & 1 & 0.40 \\
\hline 10 & Malvaceae & 8 & 3.16 & 48 & Elaeocarpaceae & 1 & 0.40 \\
\hline 11 & Aracaceae & 6 & 2.37 & 49 & Lecythidaceae & 1 & 0.40 \\
\hline 12 & Convolvulaceae & 6 & 2.37 & 50 & Liliaceae & 1 & 0.40 \\
\hline 13 & Poaceae & 6 & 2.37 & 51 & Lythraceae & 1 & 0.40 \\
\hline 14 & Rubiaceae & 6 & 2.37 & 52 & Martyniaceae & 1 & 0.40 \\
\hline 15 & Solanaceae & 6 & 2.37 & 53 & Moraceae & 1 & 0.40 \\
\hline 16 & Myrtaceae & 5 & 1.98 & 54 & Moringaceae & 1 & 0.40 \\
\hline 17 & Rutaceae & 4 & 1.58 & 55 & Musaceae & 1 & 0.40 \\
\hline 18 & Verbenaceae & 4 & 1.58 & 56 & nelumbonaceae & 1 & 0.40 \\
\hline 19 & Apiaceae & 3 & 1.19 & 57 & Nyctaginaceae & 1 & 0.40 \\
\hline 20 & Bignoniaceae & 3 & 1.19 & 58 & Nymphaeaceae & 1 & 0.40 \\
\hline 21 & Commelinaceae & 3 & 1.19 & 59 & Oleaceae & 1 & 0.40 \\
\hline 22 & Sapotaceae & 3 & 1.19 & 60 & Oxalidaceae & 1 & 0.40 \\
\hline 23 & Anacardiaceae & 2 & 0.79 & 61 & Papavarace & 1 & 0.40 \\
\hline 24 & Annonaceae & 2 & 0.79 & 62 & Pedaliaceae & 1 & 0.40 \\
\hline 25 & Apocynaceae & 2 & 0.79 & 63 & Piperaceae & 1 & 0.40 \\
\hline 26 & Brassicaceae & 2 & 0.79 & 64 & Portulacaceae & 1 & 0.40 \\
\hline 27 & Compositae & 2 & 0.79 & 65 & Punicaceae & 1 & 0.40 \\
\hline 28 & Leguminosae & 2 & 0.79 & 66 & Rhamnaceae & 1 & 0.40 \\
\hline 29 & Meliaceae & 2 & 0.79 & 67 & Sampigae & 1 & 0.40 \\
\hline 30 & Polygonaceae & 2 & 0.79 & 68 & Santalaceae & 1 & 0.40 \\
\hline 31 & Rosaceae & 2 & 0.79 & 69 & Sapindaceae & 1 & 0.40 \\
\hline 32 & Tiliaceae & 2 & 0.79 & 70 & Scorphulariaceae & 1 & 0.40 \\
\hline 33 & Agavaceae & 1 & 0.40 & 71 & Simaroubaceae & 1 & 0.40 \\
\hline 34 & Aizoaceae & 1 & 0.40 & 72 & Typhaceae & 1 & 0.40 \\
\hline 35 & Alliaceae & 1 & 0.40 & 73 & Ulmaceae & 1 & 0.40 \\
\hline 36 & Asclepidaceae & 1 & 0.40 & 74 & Urticaceae & 1 & 0.40 \\
\hline 37 & Balsaminaceae & 1 & 0.40 & 75 & Zingiberaceae & 1 & 0.40 \\
\hline 38 & Bombacaceae & 1 & 0.40 & 76 & Zygophyllaceae & 1 & 0.40 \\
\hline
\end{tabular}




\section{Fig. 1 Group wise distribution of bee flora in Madurai District during 2016-2017}

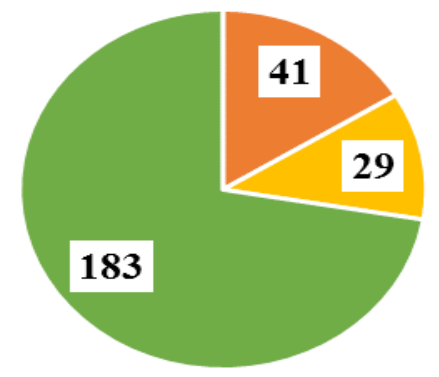

Nectar yielder $\quad$ Pollen Yielder $\quad$ Both Nectar and Pollen yielder

Similar flora for A. mellifera has been reported by Almeida-Muradian et al., (2005) and (Kumar et al., 2015). In west Bengal, melissopalynological study on Acanthaceae family revealed 70 genera and 340 species (Ghosh and Karmakar, 2012). The availability of bee foraging flora in a region decides the strength of the hive, (Bhalchandra et al., 2014) and occur according to the location and season (Ponnuchamy et al., 2014).

In the present study, grouping of bee pasturage revealed 41 nectar yielders, 29 pollen yielders and 183 of both nectar and pollen yielders (Fig. 1). This was in accordance with the study conducted in the part of Paithan Taluk of Aurangabad region which showed 63 bee flora, including 41 wild and 22 agro-horticultural plants. Similarly in agro-horticultural crops of 6 nectar yielding, 5 pollen yielding and 11 nectar and pollen yielding plants were observed (Waykar and Baviskar, 2015). The seasonal flora availability could be correlated with the observations of Behera et al., (2014). During July to August (dearth period) the A. cerana and Apis mellifera foraged on 25 different shrubs, herbs, climbers and tree species in part of south Gujarat as (Kumar et al., 2015) observed 20 different medicinal plant species belonging to thirteen families and eleven tree species, six herb species and three shrub species.

\section{Acknowledgements}

This study was supported by the Post Graduate research of the Department of Agricultural Entomology, Agricultural College and Research Institute, Tamil Nadu Agricultural University, Madurai which is gratefully acknowledged. The authors also thank the Dean Agricultural College and Research Institute, Madurai for the consistent support for the above investigation.

\section{References}

Almeida-Muradian, L. B., Pamplona, L. C., Coimbra, S., and Barth, O. M. 2005. Chemical composition and botanical evaluation of dried bee pollen pellets. Journal of Food Composition and Analysis 18(1): 105-111.

Behera, L., Sinha, A., and Abhishek, M. 2014. Suitable bee flora availability for commercial apiculture during dearth period in the heavy rainfall zone of South Gujarat. Research Journal of Chemical and Environmental Sciences 2(6): 65-68. 
Bhalchandra, W., Baviskar, R. K., and Nikam, T. B. 2014. Diversity of nectariferous and polleniferous bee flora at Anjaneri and Dugarwadi hills of Western Ghats of Nasik district (M. S.) Indian Journal of Entomology and Zoology Studies 2(4): 244-249.

Dalio J.S., 2015. Foraging behaviour of Apis mellifera on Trianthema portulacastrum. Journal of Entomology and Zoology Studies 3(2):105-108.

Egelie, A. A., Mortensen, A. N., GillettKaufman, J. L., and Ellis, J. D. 2015. common name: Asian honey bee (suggested common name) scientific name : Apis cerana Fabricius (Insecta: Hymenoptera: Apidae) introduction distribution - description - life cycle biology - economic impact management - acknowledgements selecte. University of Florida, 1-8.

Ghosh, A., and Karmakar, P. 2012. Studies in the Pollen Morphology of Some Members of Acanthaceae in Paschim Medinipur District, West Bengal. Indian Journal of Biological Sciences 26-32.

I'anson Price, R., and Grüter, C. 2015. Why, when and where did honey bee dance communication evolve? Frontiers in Ecology and Evolution 3(November), 17.

Jivan, A. 2013. The Impact of Pesticides on Honey Bees and Hence on Humans. Scientific Papers Animal Science and Biotechnologies 46(2): 272-277.

Kumar D., and Sharma V. 2016. Evaluation of Acacia Species as Honeybee Forage
Potential. International Journal of Science and Research 5(1):1726-1727.

Kumar, D., Sharma, V., and Bharti, U. 2015. Mapping of medicinal flora as honey bee forage. Journal of Entomology and Zoology Studies 3(6): 235-238.

Ponnuchamy, R., Bonhomme, V., Prasad, S., Das, L., Patel, P., Gaucherel, C., Pragasam, A., and Anupama, K. 2014. Honey pollen: Using melissopalynology to understand foraging preferences of bees in tropical south India. PLoS ONE 9(7).

Said, F., Inayatullah, M., Ahmad, S., Iqbal, T., and Shah, R. A. 2015. Foraging behavior of the Himalayan Honeybee, Apis cerana (Hymenoptera: Apidae) associated with sunflower (Helianthus annuus L.) at Peshawar District of Khyber Pakhtunkhwa (KP). Journal of Entomology and Zoology Studies 3(3): 203-207.

Sodré, G. D. S., Marchini, L. C., Carvalho, C. A. L. D. and Moreti A.C.D.C.C. 2007. Pollen analysis in honey samples from the two main producing regions. pdf. Anais da Academia Brasileira de Ciências 79: 381-388.

Theisen-Jones, H., and Bienefeld, K. 2016. The Asian Honey Bee (Apis cerana) is significantly in decline. Bee World 93(4): 90-97.

Waykar, B., and Baviskar, R. K. 2015. Diversity of bee foraging flora and floral calendar of Paithan taluka of Aurangabad district (Maharashtra), India. Journal of Applied Horticulture, 17(2): 155-159.

\section{How to cite this article:}

Hemalatha, D., J. Jayaraj, M. Murugan, T.N. Balamohan, N. Senthil, C. Chinniah and Suresh, K. 2018. Floral Diversity for Foraging of the Asiatic Honey Bee, Apis cerana indica (Hymenoptera: Apidae) in Madurai District of Tamil Nadu, India. Int.J.Curr.Microbiol.App.Sci. 7(10): 3452-3456. doi: https://doi.org/10.20546/ijcmas.2018.710.400 